\title{
PENGARUH KECERDASAN INTELEKTUAL, KECERDASAN EMOSIONAL DAN KECERDASAN SPIRITUAL TERHADAP SIKAP ETIS MAHASISWA AKUNTANSI (Studi Empiris Pada Mahasiswa Prodi Akuntansi Universitas Negeri Yogyakarta)
}

\author{
THE INFLUENCE OF INTELLECTUAL INTELLIGENCE, EMOTIONAL \\ INTELLIGENCE, AND SPIRITUAL INTELLIGENCE TOWARD THE ETHICAL \\ ATTITUDE OF THE ACCOUNTING STUDENTS (Empirical Study at Yogyakarta State \\ University)
}

\author{
Akhdan Nur Said \\ Prodi Akuntansi Universitas Negeri Yogyakarta \\ akhdannur28@gmail.com@gmail.com \\ Diana Rahmawati, \\ Staf Pengajar Jurusan Pendidikan Akuntansi Universitas Negeri Yogyakarta
}

\begin{abstract}
Abstrak: Pengaruh Kecerdasan Intelektual, Kecerdasan Emosional dan Kecerdasan Spiritual Terhadap Sikap Etis Mahasiswa Akuntansi (Studi Empiris pada Mahasiswa Prodi Akuntansi Universitas Negeri Yogyakarta)

Penelitian ini bertujuan untuk mengetahui pengaruh: (1) Kecerdasan Intelektual terhadap Sikap Etis Mahasiswa Akuntansi, (2) Kecerdasan Emosional terhadap Sikap Etis Mahasiswa Akuntansi, (3) Kecerdasan Spiritual terhadap Sikap Etis Mahasiswa Akuntansi, dan (4) Pengaruh Kecerdasan Intelektual, Kecerdasan Emosional dan Kecerdasan Spiritual secara bersama-sama terhadap Sikap Etis Mahasiswa Akuntansi. Populasi penelitian ini adalah seluruh mahasiswa angkatan 2014 dan 2015 program studi akuntansi Fakultas Ekonomi Universitas Negeri Yogyakarta. Uji prasyarat analisis meliputi uji linearitas, uji multikolinearitas dan uji heteroskedastisitas. Teknik analisis data yang digunakan adalah analisis regresi linier sederhana dan analisis regresi linier berganda. Hasil penelitian menunjukkan: (1) Kecerdasan Intelektual berpengaruh positif terhadap Sikap Etis Mahasiswa Akuntansi FE UNY, (2) Kecerdasan Emosional berpengaruh positif terhadap Sikap Etis Mahasiswa Akuntansi, (3) Kecerdasan Spiritual berpengaruh positif terhadap Sikap Etis Mahasiswa Akuntansi, dan (4) Kecerdasan Intelektual, Kecerdasan Emosional dan Kecerdasan Spiritual secara bersama-sama berpengaruh positif terhadap Sikap Etis Mahasiswa Akuntansi.
\end{abstract}

Kata Kunci: Sikap Etis Mahasiswa Akuntansi FE UNY, Kecerdasan Intelektual, Kecerdasan Emosional, Kecerdasan Spiritual.

\begin{abstract}
The Influence of Intellectual Intelligence, Emotional Intelligence, and Spiritual Intelligence toward the Ethical Attitude of the Accounting Students (Empirical Study at Yogyakarta State University)

This research aims to identify the influences of (1) the intellectual intelligence toward ethical attitude of accounting students of economics faculty in UNY, (2) the emotional intelligence toward ethical attitude of accounting students of economics faculty in UNY, (3) spiritual intelligence toward ethical attitude of accounting students of economics faculty in UNY, (4) the intellectual intelligence, the emotional intelligence and the spiritual intelligence toward ethical attitude of accounting students of economics faculty in UNY. This research used a causal comparative method. The object of this research are all of the students in 2014 and 2015 which are studying on accounting department at economic faculty, Yogyakarta state university. Multiformation test, multicollinearity test and heteroscedasticity test. Data analysis techniques used are simple linear regression analysis and multiple linear regression analysis. The results of this study indicate that (1) Intellectual Intelligence positively affect the Ethical Attitudes of Accounting Students FE UNY, (2) Emotional Intelligence positively affect the Ethical Attitudes of Accounting Students, (3) Spiritual Intelligence positively affect the Ethical Attitudes of Accounting Students, 4) Intellectual Intelligence, Emotional Intelligence and Spiritual Intelligence together positively affect the Ethical Attitudes of Accounting Student.
\end{abstract}




\section{JURNAL NOMINAL / VOLUME VII NOMOR 1 / TAHUN 2018}

Keywords: Ethical Attitudes, Intellectual Intelligence, Emotional Intelligence, Spiritual Intelligence

\section{PENDAHULUAN}

Akuntan merupakan profesi yang tumbuh dan berkembang dalam lingkungan bisnis, dimana eksistensinya dari waktu ke waktu akan selalu diakui oleh masyarakat. Penyebab adanya perkembangan ini adalah semakin banyaknya kebutuhan jasa akuntan di dunia bisnis, di pemerintah serta di masyarakat luas. Namun demikian, masyarakat belum sepenuhnya menaruh kepercayaan terhadap akuntan. Dikarenakan meningkatnya perhatian masyarakat pada isu-isu etika dalam dunia usaha dan profesi setelah maraknya terjadinya kejahatan akuntansi pada akhirakhir ini. Seperti di Indonesia, kasus Toshiba Corp pada tahun 2015, tentang penggelembungan laba sebesar 151,8 miliar yen atau 1,22 miliar dolar AS yang awalnya ingin menciptakan investor's confidence ternyata telah mencoreng nama besar Toshiba selama ini. Ada pun kasus lainnya seperti PT Katarina Utama Tbk (RINA) yang terjadi pada tahun 2010, kasus yang terkait dengan dugaan penyelewengan dana IPO dan penggelembungan aset perusahaan. Beberapa kasus tersebut membuat profesi akuntan menjadi buruk di mata masyarakat. Penyimpangan diatas ada dikarenakan sikap etis seorang akuntan yang tidak sesuai dengan prinsip yang berlaku umum. Padahal sudah jelas terdapat kode etik akuntan yang menjelaskan prinsip-prinsip etis yang harus dimiliki oleh seorang akuntan.

Di dalam pekerjaan atau organisasi, sikap adalah suatu yang penting karena sikap mempengaruhi perilaku kerja seseorang. Oleh karena itu, seorang akuntan harus mengerti bahwa dia mampu bersikap etis. Kesadaran dirinya untuk bersikap etis tersebut didorong dari kemampuan individu untuk menyadari akan suatu hal apakah hal ini termasuk hal yang benar atau salah. Berbagai penelitian tentang etika, baik etika profesi akuntan maupun etika bisnis memberikan bukti empiris mengenai faktor-faktor yang mempengaruhi sikap dan perilaku etis seseorang. Hal itu dapat dikelompokkan ke dalam tiga aspek yaitu : 1) Aspek individual; 2) Aspek organisasional; dan 3) Aspek lingkungan. Penelitian tentang etika yang berfokus pada aspek individual menunjukkan berbagai faktor yang mempengaruhi sikap dan perilaku etis seseorang antara lain adalah a) religiusitas, b) kecerdasan emosional (emotional quotient), c) gender, d) suasana etis (ethical climate) individu, e) sifat-sifat personal, dan f) kepercayaan bahwa orang lain lebih tidak etis. Sementara, aspek organisasi yang mempengaruhi sikap dan perilaku etis seseorang meliputi faktorfaktor antara lain: a) suasana etis organisasi dan b) suasana organisasi. Sedangkan aspek lingkungan yang mempengaruhi sikap dan 


\section{JURNAL NOMINAL / VOLUME VII NOMOR 1 / TAHUN 2018}

perilaku etis seseorang meliputi: a) Lingkungan organisasi, dan b) Lingkungan sosial atau masyarakat (Tikollah dkk, 2006). Dijelaskan oleh Sudibyo (1995) dalam Komsiyah dan Indriantoro (2001) bahwa dunia pendidikan akuntansi mempunyai pengaruh yang besar terhadap perilaku etis seorang akuntan. Hal ini dapat menunjukkan bahwa sikap dan perilaku etis akuntan dapat terbentuk melalui proses pendidikan yang terjadi dalam institusi pendidikan yang memiliki program studi akuntansi.

Dalam memahami akuntansi adanya kecerdasan intelektual merupakan hal yang penting juga untuk dipertimbangkan. Mahasiswa akuntansi yang memiliki kecerdasan intelektual yang baik tentu memiliki pemahaman akuntansi yang baik pula. Penelitian Ludigdo dkk (1999) menemukan bahwa kecerdasan intelektual secara stimulan maupun parsial berpengaruh signifikan terhadap sikap etis mahasiswa akuntansi. Dalam perspektif yang lain, Tikollah, Triyuwono \& Ludigno (2006) mengemukakan bahwa dunia pendidikan akuntansi mempunyai pengaruh yang besar terhadap perilaku etika auditor. Hal ini menunjukkan bahwa sikap dan perilaku etis auditor (akuntan) dapat terbentuk melalui proses pendidikan yang terjadi dalam lembaga pendidikan akuntansi, dimana mahasiswa berkaitan dengan sebagai input sedikit banyaknya akan memiliki keterkaitan dengan akuntan yang dihasilkan sebagai output. Tetapi tujuan pendidikan tidak hanya mengenai kecerdasan intelektual saja. Pendidikan juga harus dapat mengembangkan peserta didik dari segi emosi, sikap dan kemampuan spiritual. Dengan kata lain, pendidikan harus dapat mengembangkan kecerdasan emosional dan kecerdasan spiritual agar peserta didik dapat menjadi insan yang tidak hanya berilmu namun juga memiliki sikap etis.

Istilah kecerdasan emosional pertama kali diperkenalkan oleh Piter Salovey dari Harvard University dan Jhon Mayer dari University of New Hampshire. Konsep ini kemudian berkembang dengan pesat karena dianggap sebagai komponen dalam membentuk tingkah laku yang cerdas. Menurut Salovey dan Mayer (1990) dalam Tikollah (2006), kecerdasan emosional adalah kemampuan mengetahui perasaan sendiri dan perasaan orang lain, serta menggunakan perasaan tersebut untuk menuntun pikiran perilaku seseorang. Sejalan dengan hal tersebut menurut Goleman (2005:512) kecerdasan emosional adalah kemampuan untuk mengenal perasaan diri sendiri dan orang lain untuk memotivasi diri sendiri dan mengelola emosi dengan baik di dalam diri dan hubungan. Berdasarkan dua pendapat di atas dapat disimpulkan bahwa kecerdasan emosional merupakan kemampuan 


\section{JURNAL NOMINAL / VOLUME VII NOMOR 1 / TAHUN 2018}

seseorang untuk mengerti, mengenal, mengelola dan mengendalikan perasaan dan emosi diri sendiri serta orang lain sehingga terbentuklah sebuah tingkah laku cerdas yang dipadukan antara pikiran dan tindakan.

Selain kecerdasan intelektual dan kecerdasan emosional, kecerdasan lain yang tidak kalah penting yaitu kecerdasan spiritual. Kecerdasan spiritual adalah kecerdasan yang berperan penting sebagai landasan yang diperlukan untuk memfungsikan kecerdasan intelektual dan kecerdasan emosional secara efektif. Konsep kecerdasan spiritual pertama kali digagas oleh Danar Zohar dan Ian Marshall (2000). Dengan riset komprehensif mereka membuktikan bahwa sesungguhnya kecerdasan manusia yang paling tinggi itu terletak pada kecerdasan spiritualnya. Menurut mereka ada dua hal yang merupakan komponen fundamental dari kecerdasan spriritual yaitu aspek nilai dan makna. Menurut Zohar dan Marshall (2005: 178) mengklaim bahwa kecerdasan spiritual adalah inti dari segala intelegensia. Kecerdasan ini digunakan untuk menyelesaikan masalah kaidah dan nilainilai spiritual. Dengan adanya kecerdasan ini, akan membawa seseorang untuk mencapai kebahagiaan yang hakiki.

Seseorang yang mempunyai kecerdasan spiritual yang memadai mampu menerapkan ajaran agamanya secara optimal dan maksimal. Optimalisasi kecerdasan ini juga dapat membuat orang cerdas secara utuh. Paling tidak terdapat tiga komponen hidup yang lahir dari optimalisasi ini yaitu, kejernihan berpikir secara rasional, kecakapan emosi dan ketenangan hidup.

Mahasiswa akuntansi tentunya diharapkan memiliki ketiga kecerdasan di atas. Kecerdasan emosional dan kecerdasan spiritual tentunya berbeda dengan kecerdasan intelektual. Maka dari itu mahasiswa akuntansi diharapkan mampu mengoptimalisasikan ketiga kecerdasan tersebut agar dapat meraih sukses dan memiliki mental yang dapat diandalkan tanpa harus melanggar etika yang berlalu di masyarakat. Kecerdasan intelektual, kecerdasan emosional dan kecerdasan spiritual muncul karena adanya kesadaran untuk bertindak dari mahasiswa akuntansi.

Kehidupan sehari-hari mahasiswa di kampus memunculkan banyak fenomena yang menunjukkan pelanggaran etika yang mereka sadari maupun yang tidak disadari. Dari hasil observasi yang sudah dilakukan oleh peneliti, Mahasiswa Akuntansi Fakultas Ekonomi Universitas Negeri Yogyakarta masih sering melakukan pelanggaran-pelanggaran yang di anggap tidak penting, diantaranya mewakilkan presensi kepada mahasiswa yang masuk ke dalam kelas untuk mengikuti kegiatan perkuliahan dengan imbalan tertentu ataupun dengan sukarela, karena di 


\section{JURNAL NOMINAL / VOLUME VII NOMOR 1 / TAHUN 2018}

Fakultas Ekonomi Negeri Yogyakarta ada peraturan presensi minimal $75 \%$ sebagai salah satu syarat untuk mengikuti ujian semester. Pada kasus berbeda, antar sesama mahasiswa terdapat kebiasaan dimana saatsaat berlangsungnya ujian membuat catatan kecil sebagai bahan contekan. Bahkan ada kejadian mahasiswa yang membuatkan tugas untuk mahasiswa yang lain atau memberikan materi atau hasil tugas untuk di contoh atau di edit ulang.

Dapat disimpulkan bahwa mahasiswa akuntansi yang melakukan pelanggaranpelanggaran sikap etis seperti yang dikemukakan di atas sebetulnya mereka sangat menyadari tindakan mereka itu melanggar perilaku etis dan menyadari akan sanksi yang mereka terima bila pelanggaran tersebut diketahui oleh dosen. Tapi pada kenyaataannya pelanggaran-pelanggaran tersebut tetap saja terjadi dan seakan-akan bisa dibilang telah menjadi habit di kalangan mahasiswa tersebut.

Berdasarkan uraian tersebut, terdapat perbedaan hasil penelitian pengaruh langsung kecerdasan intelektual, kecerdasan emosional dan kecerdasan spiritual terhadap sikap etis mahasiswa akuntansi maka penelitian ini ingin menguji kembali faktor-faktor yang mempengaruhi sikap etis khususnya sikap etis yang terdapat di mahasiswa akuntansi Universitas Negeri Yogyakarta.
Penelitian ini difokuskan kepada sikap etis mahasiswa akuntansi yang di pengaruhi oleh faktor kecerdasan intelektual, kecerdasan emosional an kecerdasan spiritual. Mata kuliah yang bersangkutan dengan judul ini adalah Akuntansi Keperilakuan, Auditing dan Etika Bisnis.

Berdasarkan latar belakang diatas, maka peneliti tertarik untuk melakukan penelitian dengan judul "Pengaruh Kecerdasan Intelektual, Kecerdasan Emosional dan Kecerdasan Spiritual terhadap Sikap Etis Mahasiswa Akuntansi (Studi Empiris pada Mahasiswa Prodi Akuntansi Universitas Negeri Yogyakarta)"

\section{JENIS PENELITIAN}

Jenis penelitian ini merupakan kausal komparatif dengan pendekatan kuantitatif. Penelitian kausal komparatif adalah tipe penelitian dengan karakteristik masalah berupa hubungan sebab akibat antar dua variabel atau lebih. Tujuan dari penelitian kausal komparatif adalah untuk menyelidiki kemungkinan hubungan sebab-akibat dengan berdasar atas pengamatan terhadap akibat yang ada, dan mencari kembali fakta yang mungkin menjadi penyebab melalui data tertentu.

Jenis data dalam penelitian ini adalah kuantitatif yaitu data yang berbentuk angka atau data kualitatif yang diangkakan (Sugiyono, 2012:7). Dalam penelitian ini 


\section{JURNAL NOMINAL / VOLUME VII NOMOR 1 / TAHUN 2018}

yang dimaksud dengan data kuantitatif adalah jumlah responden yang menjawab kuesioner. Sumber data yang ada dalam penelitian ini adalah sumber data primer. Data primer merupakan sumber data penelitian yang diperoleh secara langsung dari sumber asli (tidak melalui media perantara). Data primer akan dikumpulkan secara khusus oleh peneliti untuk menjawab pertanyaan penelitian. Data primer pada penelitian ini meliputi jawaban responden yang diperoleh melalui penyebaran kuesioner.

\section{Sikap Etis}

Sikap etis merupakan tingkah laku perbuatan seseorang yang mampu memahami dan mengenali perilaku sesuai kode etik, mampu melakukan tindakan yang konsisten dengan nilai dan keyakinannya serta mampu bertindak berdasarkan nilai dan norma. Indikatorindikator sikap etis adalah lima item kejadian yang mengandung situasi dilematis dari perspektif prinsip etika kode etik akuntan profesional. Situasi dilematis adalah situasi yang dihadapi oleh seseorang dimana ia merasa bingung untuk mengambil suatu keputusan tentang sikap apa yang seharusnya dilakukan. Serta prinsip etika kode etik akuntan profesional mewakili pedoman bagi para akuntan akan tindakan ataupun sikap yang etis dan tidak etis di lakukan. Lima prinsip etika kode etik akuntan professional yaitu integritas, objektifitas, kehati-hatian profesional, kerahasiaan dan perilaku professional.

\section{Keceerdasan Intelektual}

Kecerdasan Intelektual merupakan kemampuan seseorang untuk memanipulasi dan menggunakan aturan aturan formal, seperti aturan tata bahasa atau dalam hal berhitung. Indikator-indikator dari kecerdasan intelektual adalah kemampuan figur, kemampuan verbal dan kemampuan numerik.

\section{Kecerdasan Emosional}

Kecerdasan Emosional merupakan kemampuan seseorang dalam kesadaran diri, kendali diri, empati, motivasi, dan keterampilan sosial. Indikator-indikator dari kecerdasan emosional adalah kesadaran kiri, kendali diri, motivasi, empati dan keterampilan sosial.

\section{Kecerdasan Spiritual}

Kecerdasan Spiritual adalah adalah kecerdasan untuk memecahkan persoalan makna dan nilai, yaitu kecerdasan untuk menempatkan perilaku dan hidup dalam konteks makna yang lebih luas, kecerdasan untuk menilai bahwa tindakan atau jalan hidup seseorang lebih bermakna dibanding dengan yang lain. Indikator kecerdasan spiritual meliputi hal-hal berikut: mutlak jujur, keterbukaan, pengetahuan diri, fokus pada kontribusi dan spriritual nondogmatis. 


\section{JURNAL NOMINAL / VOLUME VII NOMOR 1 / TAHUN 2018}

\section{HASIL PENELITIAN DAN}

PEMBAHASAN

Statistik Deskriptif

Statistik Deskriptif Sikap Etis

Sikap etis memiliki skor tertinggi sebesar 70 dan skor terendah sebesar 10. Hal tersebut menunjukkan bahwa besar Sikap Etis yang menjadi sampel penelitian ini berkisar antara 10 sampai 10 dengan nilai tengah 40 pada standar deviasi 10 .

\section{Statistik Deskriptif Kecerdasan Intelektual}

Kecerdasan Intelektual memiliki skor tertinggi sebesar 40 dan skor terendah sebesar 10. Hal tersebut menunjukkan bahwa besar Kecerdasan Intelektual yang menjadi sampel penelitian ini berkisar antara 10 sampai 40 dengan nilai tengah 25 pada standar deviasi 5 .

\section{Statistik Deskriptif Kecerdasan Emosional}

Kecerdasan Emosional memiliki skor tertinggi sebesar 40 dan skor terendah sebesar 10. Hal tersebut menunjukkan bahwa besar Kecerdasan Emosional yang menjadi sampel penelitian ini berkisar antara 10 sampai 40 dengan nilai tengah 25 pada standar deviasi 5 .

\section{Statistik Deskriptif Kecerdasan Spiritual}

Kecerdasan Spiritual memiliki skor tertinggi sebesar 40 dan skor terendah sebesar 10. hal tersebut menunjukkan bahwa besar Kecerdasan Spiritual yang menjadi sampel penelitian ini berkisar antara 10 sampai 40 dengan nilai tengah 25 pada standar deviasi 5 .

\section{Hasil Pengujian Prasyarat Analisis}

\section{Uji Linearitas}

Hasil uji Linieritas dengan menggunakan Test for Linearity diperoleh hasil untuk Kecerdasan Intelektual dengan nilai Deviation from Linearity sebesar 0,313, Kecerdasan Emosional dengan nilai Deviation from Linearity sebesar 0,158 dan Kecerdasan Spiritual dengan nilai Deviation from Linearity sebesar 0,204. Nilai tersebut berada di atas tingkat signifikansi 0,05 sehingga dapat disimpulkan bahwa data linier.

\section{Uji Multikolinieritas}

Hasil Uji Multikolinieritas diperoleh nilai Tolerance lebih besar dari 0,10 dan nilai Variance Inflation Factor (VIF) kurang dari 10,00. Sehingga dapat disimpulkan bahwa tidak ada korelasi antarvariabel independen atau model regresi pada penelitian ini tidak terjadi multikoliniearitas dan model regresi layak digunakan.

\section{Uji Heteroskedatisitas}

Hasil uji heteroskedastisitas dengan Uji Glejser menunjukkan masing-masing variabel independen memperoleh nilai signifikansi lebih besar dari 0,05. Sehingga dapat disimpulkan bahwa model regresi dalam penelitian ini tidak terjadi heteroskedastisitas.

\section{Hasil Pengujian Hipotesis dan Pembahasan} Uji Regresi Linear Sederhana

Analisis regresi linier sederhana digunakan untuk mengetahui pengaruh variabel independen secara individu terhadap variabel dependen. Hasil uji regresi linier sederhana variable independen yang terdiri dari Kecerdasan 


\section{JURNAL NOMINAL / VOLUME VII NOMOR 1 / TAHUN 2018}

Intelektual, Kecerdasan Emosional, dan Kecerdasan Spiritual secara individu terhadap Sikap Etis Mahasiswa Akuntansi adalah sebagai berikut:

Tabel 1. Hasil Uji Regresi Linier Sederhana

\begin{tabular}{lcc}
\hline Variabel & $\boldsymbol{t}$ & Sig. \\
\hline Kecerdasan Intelektual & 3,178 & 0,002 \\
\hline Kecerdasan Emosional & 2,167 & 0,032 \\
\hline Kecerdasan Spiritual & 2,600 & 0,010
\end{tabular}

\section{Pengaruh Kecerdasan Intelektual terhadap} Sikap Etis

Berdasarkan hasil uji signifikansi (uji statistik t) variabel Kecerdasan Intelektual diperoleh nilai t hitung sebesar 3,178 lebih besar dari t tabel sebesar 1,655 . Sementara nilai signifikansi 0,002 lebih kecil dari 0,05. Hal ini menunjukkan bahwa Kecerdasan Intelektual berpengaruh positif dan signifikan terhadap Sikap Etis Mahsiswa Akuntansi. Artinya semakin tinggi Kecerdasan Intelektual maka Sikap Etis Mahasiswa Akuntansi juga semakin tinggi.

\section{Pengaruh Kecerdasan Emosional terhadap} Sikap Etis

Berdasarkan hasil uji signifikansi (uji statistik t) variabel Kecerdasan Emosional diperoleh nilai t hitung sebesar 2,167 lebih besar dari t tabel sebesar 1,655. Sementara nilai signifikansi 0,032 lebih kecil dari 0,05. Hal ini menunjukkan bahwa Kecerdasan Emosional berpengaruh positif dan signifikan terhadap Sikap Etis Mahsiswa Akuntansi. Artinya semakin tinggi Kecerdasan Emosional maka Sikap Etis Mahasiswa Akuntansi juga semakin tinggi.

Pengaruh Kecerdasan Spiritual terhadap Sikap Etis

Berdasarkan hasil uji signifikansi (uji statistik t) variabel Kecerdasan Spiritual diperoleh nilai t hitung sebesar 2,600 lebih besar dari t tabel sebesar 1,655. Sementara nilai signifikansi 0,010 lebih kecil dari 0,05. Hal ini menunjukkan bahwa Kecerdasan Spiritual berpengaruh positif dan signifikan terhadap Sikap Etis Mahsiswa Akuntansi. Artinya semakin tinggi Kecerdasan Spiritual maka Sikap Etis Mahasiswa Akuntansi juga semakin tinggi.

\section{Uji Regresi Linear Berganda}

Tabel 2. Hasil Uji Regresi Linier Berganda

\begin{tabular}{llcc}
\hline & Model & F & Sig. \\
\hline 1 & Regression & 4,489 & 0,005 \\
\cline { 2 - 4 } & Residual & & \\
\cline { 2 - 3 } & Total & & \\
\hline
\end{tabular}

Pada hasil uji signifikansi simultan diperoleh nilai $\mathrm{F}$ hitung sebesar 4,489 dengan tingkat signifikansi 0,005 . Nilai tersebut lebih kecil dari 0,05 , sehingga dapat dikatakan bahwa Kecerdasan Intelektual, Kecerdasan Emosional dan Kecerdasan Spiritual secara bersama-sama memberikan pengaruh positif dan signifikan terhadap Sikap Etis Mahasiswa Akuntansi. 


\section{JURNAL NOMINAL / VOLUME VII NOMOR 1 / TAHUN 2018}

\section{SIMPULAN DAN SARAN}

\section{Simpulan}

1. Kecerdasan Intelektual berpengaruh positif dan signifikan terhadap Sikap Etis Mahasiswa Akuntansi yang ditunjukkan dengan nilai signifikansi kurang dari level of significant yaitu 0,050 atau $(0,002<0,050)$ dan nilai t hitung sebesar 3,178 lebih besar dari t tabel sebesar 1,655. Hal ini menunjukkan bahwa pengaruh Kecerdasan Intelektual terhadap Sikap Etis Mahasiswa Akuntansi bersifat positif dan signifikan, dengan demikian semakin tinggi Kecerdasan Intelektual maka akan semakin tinggi pula Sikap Etis Mahasiswa Akuntansi.

2. Kecerdasan Emosional berpengaruh positif dan signifikan terhadap Sikap Etis Mahasiswa Akuntansi yang ditunjukkan dengan nilai signifikansi kurang dari level of significant yaitu 0,050 atau $(0,032<0,050)$ dan nilai t hitung sebesar 2,167 lebih besar dari t tabel sebesar 1,655. Hal ini menunjukkan bahwa pengaruh Kecerdasan Emosional terhadap Sikap Etis Mahasiswa Akuntansi bersifat positif dan signifikan, dengan demikian semakin tinggi Kecerdasan Emosional maka akan semakin tinggi pula Sikap Etis Mahasiswa Akuntansi.

3. Kecerdasan Spiritual berpengaruh positif dan signifikan terhadap Sikap Etis
Mahasiswa Akuntansi yang ditunjukkan dengan nilai signifikansi kurang dari level of significant yaitu 0,050 atau $(0,010<0,050)$ dan nilai thitung sebesar 2,600 lebih besar dari t tabel sebesar 2,600. Hal ini menunjukkan bahwa pengaruh Kecerdasan Spritual terhadap Sikap Etis Mahasiswa Akuntansi bersifat positif dan signifikan, dengan demikian semakin tinggi Kecerdasan Spiritual maka akan semakin tinggi pula Sikap Etis Mahasiswa Akuntansi.

4. Kecerdasan Intelektual, Kecerdasan Emosional dan Kecerdasan Spiritual secara bersama-sama memberikan pengaruh positif dan signifikan terhadap Sikap Etis Mahasiswa Akuntansi.

\section{Saran}

1. Berdasarkan data hasil penelitian, skor terendah pada variabel Sikap Etis terdapat pada pernyataan "Anda seorang akuntan di perusahaan Rafa Corp. Perusahaan anda sedang di ambang kebangkrutan, atasan anda menginginkan anda untuk memanipulasi laporan keuangan perusahaan anda pada periode tersebut. Hal ini bertujuan untuk menarik para investor agar berinvestasi di perusahaan anda dan dengan cara seperti itu perusahaan akan mendapatkan asupan dana baru." Maknanya adalah mahasiswa di posisi tersebut tertekan oleh situasi dan kondisi dimana perusahaan di tempat dia bekerja sedang 


\section{JURNAL NOMINAL / VOLUME VII NOMOR 1 / TAHUN 2018}

di ambang kebangkrutan, maka dari itu mahasiswa tersebut menganggap hal tersebut bisa dapat membantu perusahaan”. Tapi seharusnya mahasiswa yang punya sikap etis yang baik, tidak melakukan hal-hal tersebut. Mahasiswa harus lebih terbiasa dengan hal-hal seperti itu dan dibiasakan untuk tetap berpegang teguh oleh kode etik dan bersikap etis yang lebih baik.

2. Berdasarkan data hasil penelitian, skor terendah pada variabel Kecerdasan Intelektual terdapat pada pernyataan "Saya memahami setiap apa yang saya baca". Maknanya adalah mahasiswa kurang dapat mengerti atau memahami dengan apa yang mahasiswa baca. Untuk meningkatkan kemampuan memahami sebuah bacaan, mahasiswa harus memperbanyak membaca agar mudah menerima maksud dan tidak terjadi adanya salah persepsi.

3. Berdasarkan data hasil penelitian, skor terendah pada variabel Kecerdasan Emosional terdapat pada pernyataan "Saya mampu memahami perspektif orang lain" Hal tersebut bermakna bahwa mahasiswa terkadang sulit untuk memahami pendapat/sudut pandang/ perpsektif orang lain. Padahal sebaiknya sebagai mahasiswa harus bisa mengerti atau memahami perspektif dari orang lain dengan cara lebih banyak berinteraksi atau berkomunikasi secara langsung dengan orang lain.
4. Berdasarkan data hasil penelitian, skor terendah pada variabel Kecerdasan Spritual terdapat pada pernyataan "Saya mampu untuk menemukan makna dan tujuan dalam hidup saya, sehingga dapat membantu saya beradaptasi dengan situasi tertekan". Padahal seharusnya sebagai seorang mahasiswa sudah harus dapat menemukan makna dan tujuan hidupnya, dengan cara lebih sering mengambil sebuah tantangan baru dan pengalaman baru. Dengan cara seperti itu mahasiswa tersebut dapat lebih mengerti dan mengenal dirinya sendiri sehingga dapat menemukan makna dan tujuan hidupnya.

5. Sebaiknya penelitian selanjutnya menambahkan faktor-faktor lain di luar penelitian ini, seperti dalam penelitian yang mungkin lebih dapat menjelaskan tentang variabel Sikap Etis Mahasiswa Akuntansi. Karena di lihat dari nilai Sumbangan efektif dan Sumbangan Relatif, dalam penelitian ini faktorfaktor kecerdasan Intelektual, Kecerdasan Emosional dan Kecerdasan Spiritual tidak terlalu banyak berpengaruh atau bisa dibilang hanya berpengaruh sedikit terhadap variabel Sikap Etis Mahasiswa Akuntansi. 


\section{JURNAL NOMINAL / VOLUME VII NOMOR 1 / TAHUN 2018}

\section{DAFTAR PUSTAKA}

Agoes, Sukirno dan I Cenik Ardana. (2009). Etika Bisnis dan Profesi. Jakarta: Salemba Empat

Agustian, Ari Ginanjar. 2001. Rahasia Sukses Membangun Kecerdasan Emosio dan Spiritual Berdasarkan 6 Rukun Iman dan 5 Rukun Islam. Cetakan Keempat. Jakarta: Agra

Agustini dan Herawati. (2010) "Pengaruh Kecerdasan Intelektual, Kecerdasan Emoisional dan Kecerdasan Spiritual terhadap Sikap Etis Mahasiswa S1 Akuntansi. Skripsi Universitas Pendidikan Ganesha Singaraja".

A.Wiramihardja, Sutardjo. (2012). Pengantar Psikologi Klinis. Bandung: PT. Refika Aditama.

Ary Ginanjar. (2009). Rahasia Sukses Membangun Kecerdasan Emosi dan Spiritual ESQ: Emotional Spiritual Quotient, Jakarta: ARGA Publishing.

Agus Nggermanto.( 2001). Quantum Quotiont, Kecerdasan Quantum, Cara Cepat Melejitkan IQ, EQ dan SQ Secara Harmoni. Bandung: Nuansa.

Arfan, I Lubis. (2010). Akuntansi Keperilakuan. Edisi Dua. Salemba Empat : Jakarta.

Casmini. (2007). Emotional Parenting. Yogyakarta: Pilar Media.

Ghozali, Imam (2011). Aplikasi Analisis Multivariate Dengan Program IBM SPSS 19 (Edisi Kelima). Semarang: Universitas Diponegoro

_, Imam. (2006). Aplikasi Analisis Multivariate Dengan Sess. Cetakan keempat. Badan Penerbit Universitas Diponegoro. Semarang.

Goleman, D. (1996). Kecerdasan Emosi: Mengapa Emotional Intelligence Lebih Tinggi Daripada IQ, Alih
Bahasa: T.Hermay. Jakarta: PT Gramedia Pustaka Utama.

-. (2000). Kecerdasan Emosi: Mengapa Emotional Intelligence Lebih Tinggi Daripada IQ, Alih Bahasa: T.Hermay. Jakarta: PT Gramedia Pustaka Utama.

-. (2001). Emotional Intelligence Untuk Mencapai Puncak Prestasi, Alih Bahasa: Alex Tri K.W, PT. Gramedia Pustaka Utama, Jakarta.

-. (2005). Kecerdasan Emosi untuk Mencapai Puncak Prestasi. Edisi Keenam. Jakarta: PT Gramedia Putaka Utama

Husein, Umar. (2011). Metode Penelitian Untuk Skripsi dan Tesis Bisnis Edisi 11. Jakarta: PT Raja Grafindo Persada

Komsiyah \& Nur Indriantoro. (2001). "Pengaruh Orientasi Etika terhadapKomitmen dan Sensivitas Etika Auditor Pemerintah di DKI Jakarta”. Jurnal Riset Akuntansi Indonesia.

Latipun. (2002). Psikologi Eksperimen. Malang: UMM Press

Leung dan Cooper. (2005). Types of ethical issues, experience, field of employment and position

Lucyanda dan Endro, (2012). Faktor-faktor yang Mempengaruhi Perilaku Etis Mahasiswa Akuntansi Universitas Bakrie. Media Research Akuntansi

Maryani, T. dan U. Ludigdo. (2001). Survei atas factor-faktor yang mempengaruhi Sikap dan Perilaku Etis Akuntan. Jurnal TEMA 2

Muhammad, Idrus. (2003). "Kecerdasan Spiritual Mahasiswa Yogyakarta”. Psikologi Phronesis, Jurnal Ilmiah dan Terapan.

Mulyadi. (2010) Sistem Akuntansi. Edisi ke-3. Cetakan ke-lima. Salemba Empat. Jakarta 


\section{JURNAL NOMINAL / VOLUME VII NOMOR 1 / TAHUN 2018}

Pabundu, Tika. (2006). Budaya Organisasi dan Peningkatan Kinerja Perusahaan. Cetakan pertama. PT Bumi Aksara. Jakarta.

Rachmi, Filia. (2010). "Pengaruh Kecerdasan Emosional, Kecerdasan Spiritual, dan Perilaku Belajar Terhadap Pemahaman Akuntansi". Semarang. Jurnal Pendidikan Akuntansi.

Jaafar, H.T Redwan (2005). Kode Etik dan Standar Audit, Diklat Pembentukan Auditor Terampil. Jakarta: BPKP

Riswan Yudhi Fahrianta, Akhmad Yafiz Syam, Saifhul Anuar Syahdan. (2012). "Pengaruh Kecerdasan Emosional Dan Kecerdasan Sppiritual Mahasiswa Akuntasi Terhadap Tingkat Pemahaman Akuntansi".

Santosa, Purbayu Budi, dan Mulyawan Hamdani. (2007). Statistika Deskriptif dalam Bidang Ekonomi dan Niaga, Penerbit Erlangga, Jakarta

Santoso, S. (2000). Buku Latihan SPSS Statistik Parametrik, Jakarta: PT. Elex Media Komputindo, Kelompok Gramedia.

Slameto. (1995). Belajar dan faktor-faktor yang mempengaruhinya. Jakarta: PT Rineka Cipta.

Sugiyono. (2012). Metode Penelitian Bisnis. Bandung : Alfabeta

Tikolah, M. Ridwan, Ludigdo, U dan. Triwuyono, I (2006). "Pengaruh Kecerdasan mosional, Intelektual dan Spiriritual terhadap sikap etis mahasiswa Akuntansi". Jurnal dalam Simposium Nasional Akuntansi 9.

Zohar, dan Ian Marshall (2000), Spiritual Intelligence, The Ultimate Intelligence. London: Bloomsburry

- (2001). Memanfaatkan Kecerdasan Spiritual dalam Berfikir
Integralistik dan Holistic untuk Memaknai Kehidupan. Bandung: Pustaka Mizan.

- (2002). SQ : Memanfaatkan SQ dalam Berpikir Holistik Untuk Memaknai Kehidupan. Cetakan kelima.

Terjemahan Oleh Rahmania Astuti, Ahmad Nadjib Burhani \& Ahmad Baiquni. Bandung: Mizan.

-. (2005). Spiritual Capital. Bandung: Mizan

-. (2007). Kecerdasan Spiritual. Mizan Pustaka. Bandung

Zakiyah, Farah. (2013). "Pengaruh Kecerdasan Emosioanal dan Kecerdasan Spiritual Terhadap Pemahaman Akuntansi" Studi Empiris Mahasiswa Jurusan Akuntansi di Universitas Jember. 